\title{
Photosynthesis and biomass accumulation in Carapa surinamensis (Meliaceae) in response to water stress at ambient and elevated $\mathrm{CO}_{2}$
}

\author{
M.F. OLIVEIRA* and R.A. MARENCO**,+ \\ Botany Graduate Program, National Institute for Research in the Amazon (INPA), Avenida André Araújo, 2936, \\ 69067-375, Manaus - AM, Brazil* \\ Coordination of Environmental Dynamic, National Institute for Research in the Amazon (INPA), Avenida André \\ Araújo, 2936, 69067-375, Manaus - AM, Brazil ${ }^{* *}$
}

\begin{abstract}
Climate models predict an increase in atmospheric $\mathrm{CO}_{2}$ concentration and prolonged droughts in some parts of the Amazon, but the effect of elevated $\mathrm{CO}_{2}$ is still unknown. Two experiments (ambient $\mathrm{CO}_{2}-400 \mathrm{ppm}$ and elevated $\mathrm{CO}_{2}-700 \mathrm{ppm}$ ) were conducted to assess the effect of drought (soil at 50\% field capacity) on physiological parameters of Carapa. At ambient $\mathrm{CO}_{2}$ concentration, light-saturated net photosynthetic rate $\left(P_{\mathrm{Nsat}}\right)$ was reduced by $33.5 \%$ and stomatal conductance $\left(g_{\mathrm{s}}\right)$ by $46.4 \%$ under drought, but the effect of drought on $P_{\mathrm{Nsat}}$ and $g_{\mathrm{s}}$ was nullified at elevated $\mathrm{CO}_{2}$. Total plant biomass and leaf area production were also reduced (42-47\%) by drought. By changing leaf traits, Carapa is able to endure drought, as the consumptive use of water was reduced under drought (32-40\%). The improvement of $P_{\text {Nsat }}$ under elevated $\mathrm{CO}_{2}$ and water stress and the leaf plasticity of Carapa broaden our understanding of the physiology of Amazonian trees.
\end{abstract}

Additional key words: chlorophyll fluorescence; leaf water potential; nonphotochemical quenching; water-use efficiency.

\section{Introduction}

The Amazon rainforest stores about $86 \mathrm{Pg}$ of carbon in total biomass and it is estimated that about $50 \%$ of incident annual rainfall on the region is recycled by transpiration (Salati 1987, Saatchi et al. 2007). At a global scale, climate models predict an increase in temperature and atmospheric $\mathrm{CO}_{2}$ concentration, which can reach up to about $900 \mathrm{ppm}$ by 2100 (Way et al. 2015). Although the current length of the dry season seems to have little effect on tree growth rates in the central Amazon (Dias and Marenco 2016, Camargo and Marenco 2017), climate models predict expansion of areas affected by droughts in some parts of the Amazon (Cox et al. 2004, Duffy et al. 2015). In the short term, exposure to elevated $\mathrm{CO}_{2}$ enhances photosynthetic rates of $\mathrm{C}_{3}$ plants (Kirschbaum 1994, Ainsworth and Rogers 2007, Way et al. 2015) by increasing the maximum carboxylation rate of Rubisco $-V_{\text {cmax }}$ (Rubisco is substrate-limited at current $\mathrm{CO}_{2}$ concentrations) and reducing photorespiration. Most of the time, plants under elevated $\mathrm{CO}_{2}$ reduce $g_{\mathrm{s}}$ (Ainsworth and Rogers 2007, Leakey et al. 2012), which can improve water-use efficiency. On the other hand, longterm exposure to elevated $\mathrm{CO}_{2}$ can lead to photosynthetic acclimation - a downward regulation of photosynthetic enhancement under elevated $\mathrm{CO}_{2}$ (Gunderson and Wullschleger 1994, Way et al. 2015). Acclimation can be the result of a lesser amount of mineral nutrients (e.g., nitrogen) allocated to enzymes of the Calvin cycle and more assimilates partitioned to plant tissues not directly involved in carbon assimilation (Leakey et al. 2012). Thus, photosynthetic acclimation can occur in response to a reduced sink size (source-sink imbalance), changes

Received 19 April 2018, accepted 20 July 2018.

${ }^{+}$Corresponding author; phone: 55923643 1841, e-mail: rmarenco@inpa.gov.br

Abbreviations: $\mathrm{A}_{\mathrm{L}}$ - total leaf area; $\mathrm{Chl}$ - chlorophyll; $\mathrm{C}_{\mathrm{i}}$ - intercellular $\mathrm{CO}_{2}$ concentration; $\mathrm{CUW}$ - consumptive use of water; ETR electron transport rate; $\mathrm{FC}$ - field capacity; $\mathrm{F}_{\mathrm{m}}$ - maximal fluorescence yield of the dark-adapted state; $\mathrm{F}_{\mathrm{m}}$ ' - maximal fluorescence yield of the light-adapted state; $F_{s}-$ steady-state fluorescence yield; $F_{v} / F_{m}-$ maximal quantum yield of PSII photochemistry; $F_{v}-$ variable fluorescence; $g_{\mathrm{s}}-$ stomatal conductance; $J_{\max }$ - maximum electron transport rate; $\mathrm{F}_{0}$ - minimal fluorescence yield of the dark-adapted state; $J_{\max 25}-J_{\max }$ at $25^{\circ} \mathrm{C}$; LMA - leaf mass per area ratio; NPQ - nonphotochemical quenching; $T$ - temperature in Kelvin; $P_{N}-$ net photosynthetic rate; $P_{\mathrm{Nsat}}-$ light-saturated $P_{\mathrm{N}} ; P_{\mathrm{Nmax}}-$ light- and $\mathrm{CO}_{2}$-saturated $P_{\mathrm{N}} ; \mathrm{RH}-$ relative humidity; TNC - total non-structural carbohydrates; $V_{\text {cmax }}$ - maximum carboxylation rate of Rubisco; $V_{\text {cmax } 25}-V_{\text {cmax }}$ at $25^{\circ} \mathrm{C} ; \mathrm{VPD}_{\mathrm{L}}$ - leaf-to-air vapor pressure difference; $\mathrm{W}_{\mathrm{T}}$ - total dry matter (biomass); $\mathrm{WUE}_{\mathrm{i}}$ - intrinsic water-use efficiency; $\Gamma-\mathrm{CO}_{2}$-compensation point; $\Gamma^{*}-\Gamma$ in absence of mitochondrial respiration; $\Psi_{\mathrm{L}}$ - leaf water potential; $\Phi_{\mathrm{PSII}}-$ effective quantum yield of PSII photochemistry.

Acknowledgments: To the Ministry of Science, Technology, Innovations and Communications (MCTIC/ INPA PRJ 15.120), National Council for Scientific and Technological Development - CNPq (Grant 302041/2015-0 and scholarship for MFO) and Fundação de Amparo à Pesquisa do Estado do Amazonas (FAPEAM) for supporting this research. We thank the Editor and the anonymous reviewers and for their constructive and useful comments. 
in leaf carbohydrate signaling, root growth restriction, or low availability of mineral nutrients (Rogers et al. 1998, Moore et al. 1999).

Besides the increase in $\mathrm{CO}_{2}$ concentration, global models also predict that climate change can lead to an increase of the length of the dry season in some parts of the Amazon region (Cox et al. 2004, Duffy et al. 2015), which can lead to lowering net photosynthetic rate $\left(P_{\mathrm{N}}\right)$, as under water stress $P_{\mathrm{N}}$ can be substantially decreased. It has been postulated, however, that the progressive increase in atmospheric $\mathrm{CO}_{2}$ concentration can result in a greater crop yield and greater primary productivity of tropical forests (Lloyd and Farquhar 2008, Leakey et al. 2012).

Light not used in photochemical reactions (excess of light) may induce overexcitation of chlorophyll (Chl) $a$, and lead to the formation of highly reactive Chl molecules - triplet state Chl, ${ }^{3} \mathrm{Chl}$ (Papageorgiou and Govindjee 2014). The ${ }^{3} \mathrm{Chl}$ can interact with molecular oxygen and promote the production of strong oxidants (e.g., $\mathrm{O}^{2--}, \mathrm{H}_{2} \mathrm{O}_{2}$, singlet oxygen $-{ }^{1} \mathrm{O}_{2}$ ) and peroxidation of membrane lipids, which lowers the photochemical efficiency of the leaf (Papageorgiou and Govindjee 2014). Nonphotochemical quenching (NPQ), an indicator of the thylakoid transmembrane $\mathrm{pH}$ gradient, triggers enzymatic and nonenzymatic (physicochemical) reactions that lead to the dissipation of excess excitation energy as heat (Maxwell and Johnson 2000, Papageorgiou and Govindjee 2014). Therefore, NPQ is a mechanism to avoid photooxidative damage and it increases with progressive stress (Tezara et al. 1999, Liu et al. 2017).

Although the Amazon is of great importance in the global scenario, little is known about how Amazonian tree species would respond to the combined effect of elevated $\mathrm{CO}_{2}$ and water stress. In this work we hypothesized that plants subjected to elevated $\mathrm{CO}_{2}$ accumulate more biomass, increase photosynthetic rates, and improve intrinsic wateruse efficiency $\left(\mathrm{WUE}_{\mathrm{i}}\right)$. Another premise was that the photochemical efficiency of the leaf is enhanced in plants subjected to $\mathrm{CO}_{2}$ enrichment. Thus, the aim of this study was to assess photosynthetic rates and the photochemical efficiency and growth of young trees of Carapa in response to water stress under two growth conditions, ambient and elevated $\mathrm{CO}_{2}$.

\section{Materials and methods}

Plant material and growth environments: Two experiments were carried out at the National Institute for Research in the Amazon - INPA (03 $05^{\prime} 29^{\prime}$ 'S, 59 59'35" W), Manaus, AM. In Manaus, annual mean rainfall, temperature, and solar radiation are $2,300 \mathrm{~mm}, 26.5^{\circ} \mathrm{C}$, and 18.03 $\mathrm{MJ}$ day $^{-1}$, respectively (http://www.inmet.gov. br/portal/, period of 1961-1990). One experiment was conducted at ambient $\mathrm{CO}_{2}$ conditions (about $400 \mathrm{ppm}$ ) under a greenhouse conditions (hereinafter referred to
Experiment 1) and the second in a growth chamber at elevated $\mathrm{CO}_{2}-700$ ppm (Experiment 2). In both experiments, seeds of Carapa surinamensis Miq (Meliaceae, hereinafter Carapa) were germinated in vermiculite and $15 \mathrm{~d}$ after emergence, the plants were transferred to pots containing $7 \mathrm{~kg}$ of substrate (a mixture of soil of the first $20 \mathrm{~cm}$ of the soil forest, amended with mulched material and NPK (5 $\left.\mathrm{g} \mathrm{kg}^{-1}, 10: 10: 10\right)$. Six months later, the 0.6-m tall plants were randomly sorted into two groups of ten plants, one group for Experiment 1 (under greenhouse) and the second for Experiment 2, the latter to be conducted under growth chamber conditions. Both experiments lasted $163 \mathrm{~d}$ (hereinafter referred to as the experimental period, 14 July-23 December, 2015).

Experiment 1 - under greenhouse conditions: Before initiating the experiment and for several days, we measured the light conditions (PAR) inside the greenhouse, which turned out to be about $8.6 \mathrm{~mol} \mathrm{~m}^{-2} \mathrm{~d}^{-1}$, and because its latitudinal location $\left(-3.091^{\circ}\right)$ incoming irradiance remained rather constant throughout the year. We used this data to serve as a reference for setting the light intensity in the growth chamber (Experiment 2).

The treatments in this experiment were two water regimes (five plants per treatment): moderate drought (induced by keeping the soil at 50\% field capacity FC) and soil at 100\% FC (well-watered plants). In the greenhouse, PAR, temperature, and relative humidity $(\mathrm{RH})$ were measured using specific sensors ( $\mathrm{Li}-190 \mathrm{SA}, \mathrm{Li}$-Cor, Lincoln, US and Humitter 50Y, Vaisala, Oyj, Finland) connected to a datalogger ( $\mathrm{Li}$-1400, Li-Cor, Lincoln, US), which was set to record data at 15 -min intervals. Also, the $\mathrm{CO}_{2}$ concentration was measured on randomly selected days using an infrared gas analyzer ( $\mathrm{Li}$-6400XT, Li-Cor, Lincoln, US) with empty chamber.

Before submitting the plants to the water regimes, we determined the water volume the soil could hold at field capacity (100\% FC). Half of that value was used in the soil to be kept at 50\% FC. Every morning (7:00-8:00) during the whole experimental period, we determined the mass of each potted plant (accuracy of $1 \mathrm{~g}$ ) and restored the volume of water required to keep the soil at its target water content ( 50 or $100 \%$ FC). For further information, we also measured soil moisture with an electronic device (MPM-160B, ICT International, Armidale, Australia). The experimental period of $163 \mathrm{~d}$ was long enough for the plant to flush new leaves, which were used for gas-exchange measurements and laboratory analyses.

Experiment 2 - under growth chamber conditions: In this experiment, we also assessed the effect of two water regimes (soil at 50\% FC and soil at 100\% FC), which followed the same protocol as described for Experiment 1. The growth chamber (TPC-19, Biochambers, Winnipeg, Canada) has a working area of $1.72 \mathrm{~m}^{2}$ and $1.52 \mathrm{~m}$ height, 
and hence it provides enough room for the plants (five per treatment) to grow for $163 \mathrm{~d}$. Electronic devices were used to keep constant the ambient conditions in the growth chamber. $\mathrm{CO}_{2}$ concentration was set at $700 \mathrm{ppm}$, day/ night temperature at $27 / 25^{\circ} \mathrm{C}$. The $\mathrm{RH}$ inside the growth chamber was $80-90 \%$. We set the light intensity at 200 $\mu$ mol(photon) $\mathrm{m}^{-2} \mathrm{~s}^{-1}$ (i.e., $8.6 \mathrm{~mol} \mathrm{~m}^{-2} \mathrm{~d}^{-1}$ over a $12-\mathrm{h}$ photoperiod). We used this light intensity to emulate that of the greenhouse, so that some comparisons could be made at the end of the study.

In both experiments and at the end of the experimental period (163 d), we measured gas exchange, Chl fluorescence, total dry matter $\left(\mathrm{W}_{\mathrm{T}}\right)$, leaflet number, and size and total leaf area $\left(\mathrm{A}_{\mathrm{L}}\right)$, leaf mass per area ratio (LMA), proline, and total nonstructural carbohydrate (TNC) content of leaves.

Gas exchange was measured with a portable gasexchange system ( $\mathrm{Li}-6400 X \mathrm{X}, \mathrm{Li}$-Cor, Lincoln, US). The measurements were carried out between 08:00 and 14:00 $\mathrm{h}$ in two fully expanded leaves per plant, which had been produced during the experimental period. Gas exchange was measured after a stabilization period of about $10 \mathrm{~min}$ at $\left[\mathrm{CO}_{2}\right]$ of $400 \mathrm{ppm}$ in the leaf chamber (about $240 \mathrm{ppm}$ of internal $\mathrm{CO}_{2}$ concentration $-C_{\mathrm{i}}$ ) and 250-500 $\mu \mathrm{mol}$ $\mathrm{m}^{-2} \mathrm{~s}^{-1} \cdot P_{\mathrm{N}} / C_{\mathrm{i}}$ response curves were generated at light saturation $\left[1,000 \mu \mathrm{mol}\left(\right.\right.$ photon) $\mathrm{m}^{-2} \mathrm{~s}^{-1}$, this PAR value was determined after constructing a light-response curve], ambient temperature $\left(27^{\circ} \mathrm{C}\right)$, relative humidity of $70 \pm 5 \%$, and air flow of $500 \mu \mathrm{mol} \mathrm{s}{ }^{-1}$. $\mathrm{CO}_{2}$ concentration in the leaf chamber was changed step by step as previously described (Nascimento and Marenco 2013). Light-saturated net photosynthetic rate $\left(P_{\text {Nsat }}\right)$ and stomatal conductance $\left(g_{\mathrm{s}}\right)$ were measured at a light intensity of $1,000 \mu \mathrm{mol}($ photon) $\mathrm{m}^{-2} \mathrm{~s}^{-1}$ and $\mathrm{CO}_{2}$ concentration of $400 \mathrm{ppm}$ (Experiment 1 ) and $700 \mathrm{ppm}$ (Experiment 2). The last $\mathrm{CO}_{2}$ point of the $P_{\mathrm{N}} /$ $C_{\mathrm{i}}$ curve $(2,000 \mathrm{ppm}$ in the leaf chamber) corresponded to the light and $\mathrm{CO}_{2}$-saturated net photosynthetic rate $\left(P_{\mathrm{Nmax}}\right)$. Intrinsic water-use efficiency $\left(\mathrm{WUE}_{\mathrm{i}}\right)$ was determined as the $P_{\text {Nsat }} / g_{\mathrm{s}}$ ratio, and the consumptive use of water (CUW, on a leaf area basis) was determined by every morning recording the amount of water daily added to plants (to keep the soil at $50 \%$ or $100 \%$ FC). The maximum carboxylation rate of Rubisco $\left(V_{\text {cmax }}\right)$ and maximum electron transport rate $\left(J_{\max }\right)$ were calculated using the classic Faquhar's model (Farquhar et al. 1980), and the parameters described by von Caemmerer (2000):

$$
\begin{aligned}
& P_{\mathrm{Nc}}=\left[V_{\mathrm{cmax}}\left(C_{\mathrm{i}}-\Gamma^{*}\right)\right] /\left[C_{\mathrm{i}}+K_{\mathrm{c}}\left(1+O / K_{\mathrm{o}}\right)\right] \\
& P_{\mathrm{Nj}}=\left[J_{\max }\left(C_{\mathrm{i}}-\Gamma^{*}\right)\right] /\left(\left[4 C_{\mathrm{i}}+8 \Gamma^{*}\right)\right]
\end{aligned}
$$

where $P_{\mathrm{Nc}}$ and $P_{\mathrm{Nj}}$ denote $P_{\mathrm{N}}$ limited by either Rubisco activity or RuBP concentration, respectively; $\Gamma^{*}$ represents the $\mathrm{CO}_{2}$-compensation point in the absence of mitochondrial respiration $\left(37.0 \mathrm{ppm}\right.$, at $\left.25^{\circ} \mathrm{C}\right) ; O$, the intercellular oxygen concentration $\left(0.210 \mathrm{~mol} \mathrm{~mol}^{-1}\right.$, at $\left.25^{\circ} \mathrm{C}\right) ; K_{c}\left(404 \mu \mathrm{mol} \mathrm{mol}{ }^{-1}\right.$, at $\left.25^{\circ} \mathrm{C}\right)$ and $K_{\mathrm{o}}(248 \mathrm{mmol}$ $\mathrm{mol}^{-1}$, at $\left.25^{\circ} \mathrm{C}\right)$ represent the Michaelis constants of Rubisco for carboxylation and oxygenation, respectively. $V_{\text {cmax }}$ and $J_{\max }$ data were standardized to $25^{\circ} \mathrm{C}\left(V_{c \max 25}\right.$, $J_{\max 25}$ ) as follows (von Caemmerer 2000):

$$
J_{\max }=J_{\max 25} \exp \left(\frac{E_{\mathrm{aj}}(T-298)}{(298 R T)}\right) \frac{\left[1+\exp \left(\frac{298 S-H}{(298 R]}\right)\right]}{\left[1+\exp \left(\frac{S T-H}{R T}\right)\right]}
$$

$$
V_{\mathrm{cmax}}=V_{\mathrm{cmax} 25} \exp \left(\frac{E_{\mathrm{gv}}(T-298)}{(298 R T)}\right)
$$

where, $T$ is leaf temperature (in Kelvin), $R$ is the gas constant $\left(8.314 \mathrm{~J} \mathrm{~K}^{-1} \mathrm{~mol}^{-1}\right) ; E_{\mathrm{aj}}$ is activation energy for electron transport $\left(37.0 \mathrm{~kJ} \mathrm{~mol}^{-1}\right) ; S$ is entropy of activation $\left(0.71 \mathrm{~kJ} \mathrm{~K}^{-1} \mathrm{~mol}^{-1}\right)$; $H$ is enthalpy of activation $(220 \mathrm{~kJ}$ $\left.\mathrm{mol}^{-1}\right) ; E_{\mathrm{av}}$ is activation energy for carboxylation (59.36 $\mathrm{kJ} \mathrm{mol}^{-1}$ ).

Chl fluorescence was measured under ambient conditions $\left(\mathrm{CO}_{2}\right.$ of about $400 \mathrm{ppm}$ and $\left.27^{\circ} \mathrm{C}\right)$ with a portable modulated fluorometer (PAM-2500, Walz $\mathrm{GmbH}$, Effeltrich, Germany). For these measurements, we used the same leaves we had used to measure gas exchange. Early in the morning $(06: 00 \mathrm{~h})$ on a 12-h dark-adapted leaf, maximal fluorescence yield of the dark-adapted leaf $\left(\mathrm{F}_{\mathrm{m}}\right)$ was determined by applying a saturating light pulse of $6,000 \mu \mathrm{mol}$ (photon) $\mathrm{m}^{-2} \mathrm{~s}^{-1}, 1.0-\mathrm{s}$ duration. At midday (11:00-12:00 h) and under actinic light [230 $\mu \mathrm{mol}$ (photon) $\mathrm{m}^{-2} \mathrm{~s}^{-1}$ ] we also determined the effective quantum yield of PSII photochemistry $\left(\Phi_{\text {PSII }}\right)$, electron transport rate (ETR), and nonphotochemical quenching (NPQ), as follows (Maxwell and Johnson 2000):

$$
\begin{aligned}
& \mathrm{F}_{\mathrm{v}} / \mathrm{F}_{\mathrm{m}}=\left(\mathrm{F}_{\mathrm{m}}-\mathrm{F}_{0}\right) / \mathrm{F}_{\mathrm{m}}, \\
& \Phi_{\text {PSII }}=\left(\mathrm{F}_{\mathrm{m}}{ }^{\prime}-\mathrm{F}_{\mathrm{s}}\right) / \mathrm{F}_{\mathrm{m}}, \\
& \mathrm{ETR}=0.5\left(I_{\mathrm{e}} \times \Phi_{\text {PSII }}\right) \\
& \mathrm{NPQ}=\left(\mathrm{F}_{\mathrm{m}}-\mathrm{F}_{\mathrm{m}}{ }^{\prime}\right) / \mathrm{F}_{\mathrm{m}},
\end{aligned}
$$

where $F_{0}$ and $F_{m}$ denote the minimal and maximal fluorescence yield of the dark-adapted state; $F_{v} / F_{m}$ stands for the maximal quantum yield of PSII photochemistry; $F_{s}$ and $\mathrm{F}_{\mathrm{m}}$ ' represent steady-state and maximal fluorescence yield of the light-adapted state, respectively; $I_{\mathrm{e}}$ indicates the PAR absorbed by the leaf, 0.5 is the fraction of quanta absorbed by PSII relative to PSI.

Proline content was determined in fresh leaf samples. A leaf sample was placed in a test tube containing $2 \mathrm{ml}$ of ethanol and boiled in water bath until ethanol evaporation. In sequence, $2 \mathrm{ml}$ of water was added, the tube was agitated and centrifuged $(5 \mathrm{~min}, 5,000 \times g)$, and a $100-\mu 1$ extract was added to $1 \mathrm{ml}$ of $1 \%$ ninhydrin (w/v, aqueous solution in $60 \%$ acetic acid). After reaction at $95^{\circ} \mathrm{C}$ 
(20 min), the sample was cooled down to room temperature and then toluene was added $(3 \mathrm{ml})$ and the sample left to stand for phase separation. The absorbance was read at $520 \mathrm{~nm}$ (Gibon et al. 2000). Total nonstructural carbohydrates (TNC) of leaves were assessed by hydrolyzing the starch in the leaf sample with $0.5 \mathrm{M} \mathrm{NAOH}$ and the precipitate removed by centrifugation $(15 \mathrm{~min}$ at $1,000 \times g$ ). After reaction with phenol-sulfuric acid, the absorbance of the sample was recorded at $490 \mathrm{~nm}$. LMA was calculated as the leaf mass to leaf area ratio, we also determined leaflet size (leaf area) with an area meter ( $\mathrm{Li}$ 3000, Li-Cor, Lincoln, US). Total dry matter of plants $\left(\mathrm{W}_{\mathrm{T}}\right)$ was obtained by oven-drying at $72^{\circ} \mathrm{C}$ to constant mass. Leaf water potential $\left(\Psi_{\mathrm{L}}\right)$ was determined at 06:00 and 12:00 $\mathrm{h}$ in one leaf per plant with a pressure chamber (1505 D, PMS Instrument Company, Albany, USA).

Statistical analysis: Light intensity and temperature were similar in both experiments, but the relative humidity inside the growth chamber was a little higher than that in the greenhouse. Although temperature and light intensity were similar in both environments [mean PAR of about $8.6 \mathrm{~mol}$ (photon) $\mathrm{m}^{-2} \mathrm{~d}^{-1}$ ], light quality could be different, so instead of analyzing the whole study as a factorial experiment $(2 \times 2)$ we analyzed the data as two separate experiments. Each experiment was a completely randomized design with two treatments (50 and 100\% FC) and five replications (plants) per treatment. Data were subjected to analysis of variance (ANOVA). Statistical analyzes were performed using SigmaPlot 11.0 (Systat Software, Richmond, USA).

\section{Results}

\section{Experiment 1}

The physical environment: In the greenhouse, $\mathrm{RH}$ was $70-80 \%$ and mean temperature of $27.5^{\circ} \mathrm{C}$ (ranging from $26^{\circ} \mathrm{C}$ at night to $29^{\circ} \mathrm{C}$ at midday), and mean ambient $\mathrm{CO}_{2}$ concentration was $410 \pm 17 \mathrm{ppm}$ (day/night of 400/420 ppm). Confirming previous PAR data, PAR ranged from 7.99 to $9.28 \mathrm{~mol}$ (photon) $\mathrm{m}^{-2} \mathrm{~d}^{-1}$. During the experimental periods, soil moisture (measured in the morning) remained at $21 \%(50 \% \mathrm{FC})$ and $31 \%$, in the soil at $100 \% \mathrm{FC}$.

Physiological parameters: In Experiment 1 (ambient $\left.\mathrm{CO}_{2}\right), P_{\mathrm{Nsat}}, P_{\mathrm{Nmax}}$, and $g_{\mathrm{s}}$ decreased by $33.5,21.1$, and $46.4 \%$ under water stress, whereas $V_{\mathrm{cmax} 25}$ and $J_{\max 25}$ decreased by 19.1 and $16.4 \%$, respectively. $\mathrm{WUE}_{\mathrm{i}}$ increased by $24 \%$ under drought (Table 1), consistent with a reduction of CUW (32.2\%) under water stress (Fig. 1, $P$ values in Table 2). There was no effect of drought on the $\mathrm{CO}_{2}$ compensation point $(\Gamma), \operatorname{VPD}_{\mathrm{L}}$ (Table 1$)$, the $\mathrm{F}_{\mathrm{v}} / \mathrm{F}_{\mathrm{m}}$ ratio and NPQ, but $\Phi_{\text {PSII }}$ and ETR decreased about $28 \%$ under drought (Fig. 2), whereas and LMA increased by $8.3 \%$ under water stress (Fig. 3A). Although, the proline content (Table 1) and TNC and were not affected by drought, $\mathrm{W}_{\mathrm{T}}$ and $A_{\mathrm{L}}$ decreased by 42 and $48 \%$, respectively, under water stress (Fig. 3). Regarding plant allometry, leaf number, leaflet number, and leaf size were reduced by $30-40 \%$ under drought (Table 1). Leaf water potential $\left(\Psi_{\mathrm{L}}\right)$ ranged from $-0.21 \mathrm{MPa}$ (in well-watered plants at 06:00 h) to $-0.78 \mathrm{MPa}$ at midday under water stress (Table 1 ).

\section{Experiment 2}

Physiological parameters: Under elevated $\mathrm{CO}_{2}$, there was no effect of drought on $P_{\text {Nsat }}, P_{\text {Nmax }}, g_{\mathrm{s}}, V_{\text {cmax } 25}$, and $J_{\max 25}$ (Fig. 1, Table 2). The same was true for $\mathrm{VPD}_{\mathrm{L}}, \Gamma$, and WUE $_{\mathrm{i}}$ (Table 1), the $\mathrm{F}_{\mathrm{v}} / \mathrm{F}_{\mathrm{m}}$ ratio and NPQ (Fig. $2 A, D$ ), and LMA (Fig. $3 A$ ), which were not affected by water stress. On the other hand, CUW was reduced by $40 \%$ under drought (Fig. $1 D)$, and ETR and $\Phi_{\text {PSII }}$ were $32 \%$ lower in water-stressed plants (Fig. $2 B, C$ ). Similar to that what we found under ambient $\mathrm{CO}_{2}$ conditions, proline (Table 1) and TNC contents of leaves were not affected by water stress (Fig. 3B). Total leaf area $\left(\mathrm{A}_{\mathrm{L}}\right)$ and $\mathrm{W}_{\mathrm{T}}$ were reduced by $41 \%$ under water stress (Fig. 3C,D), and with respect to plant allometry, leaf and leaflet number were not affected by drought, but in agreement with the results of Experiment 1 , the leaflet size was reduced $(40.6 \%)$ under water stress (Tables 1, 2). Leaf water potential $\left(\Psi_{\mathrm{L}}\right)$ measured early in the morning and at midday were slightly higher than those recorded in Experiment 1. The $\Psi_{\mathrm{L}}$ ranged from $-0.19 \mathrm{MPa}$ in well-water plants (at 06:00 h) to $-0.53 \mathrm{MPa}$ at midday under water stress (Table 1), and during the experimental periods soil moisture (on a percentage basis) was as described for Experiment 1.

Comparison between experiments: In comparison to plants grown under ambient $\mathrm{CO}_{2}, P_{\text {Nsat }}$ increased by $64 \%$ (6.21 to $10.21 \mu \mathrm{mol} \mathrm{m} \mathrm{m}^{-2} \mathrm{~s}^{-1}$ ) under elevated $\mathrm{CO}_{2}$ in wellwatered plants, and 153\% (4.13-10.43 $\left.\mu \mathrm{mol} \mathrm{m} \mathrm{m}^{-2} \mathrm{~s}^{-1}\right)$ in plants subjected to water stress (Fig. $1 A$ ). In well-watered plants, $g_{\mathrm{s}}$ was lower under elevated $\mathrm{CO}_{2}$, with a reduction of $24 \%\left(0.084\right.$ to $\left.0.064 \mathrm{~mol} \mathrm{~m}^{-2} \mathrm{~s}^{-1}\right)$. Compared to ambient $\mathrm{CO}_{2}, g_{\mathrm{s}}$ increased by $49 \%$ under elevated $\mathrm{CO}_{2}$ in waterstressed plants. Therefore, $g_{\mathrm{s}}$ was similar between water regimes under elevated $\mathrm{CO}_{2}$ (mean of $0.066 \mathrm{~mol} \mathrm{~m}^{-2} \mathrm{~s}^{-1}$, Fig. $1 B$ ). It is important to note that $\mathrm{VPD}_{\mathrm{L}}$ was similar in both experiments, with a mean of $1.58 \mathrm{kPa}$ (Table 1). Over water regimes, mean $P_{\text {Nmax }}$ values were similar in both $\mathrm{CO}_{2}$ experiments (Fig. 1C). It is also worth noting that drought had a lesser effect on $J_{\max 25}$ and $V_{\mathrm{cmax} 25}$ at elevated $\mathrm{CO}_{2}$ (Fig. $1 E, F)$, and across experiments, the $J_{\max 25} / V_{\mathrm{cmax} 25}$ ratio was about 1.80 , with a high correlation $(r=0.80, P<0.001)$. The $\mathrm{CO}_{2}$-compensation point $(\Gamma)$ showed little variation over experiments (Table 1), with a general mean of $58 \mathrm{ppm}$. In comparison with plants grown in ambient $\mathrm{CO}_{2}, \mathrm{WUE}_{\mathrm{i}}$ improved by $86 \%$ under elevated $\mathrm{CO}_{2}$ (Table 1 ). Although $\mathrm{WUE}_{\mathrm{i}}$ only increased under water stress at ambient $\mathrm{CO}_{2}$ (Table 1), in both experiments, the CUW was lower under water stress (32-40\%). Neither elevated $\mathrm{CO}_{2}$ nor drought affected the $\mathrm{F}_{\mathrm{v}} / \mathrm{F}_{\mathrm{m}}$ ratio, but in both experiments, $\Phi_{\mathrm{PSII}}$ and ETR were about $30 \%$ lower in the plants subjected to water stress. However, within a water regime, $\Phi_{\text {PSII }}$ and ETR were similar in both experiments (Fig. 2B,C). Contrary to expectation, there was no effect of water regimes on NPQ, but on average, plants grown under enriched $\mathrm{CO}_{2}$ 
Table 1. Leaf water potential $\left(\Psi_{\mathrm{L}}\right)$, leaf proline content, leaf and leaflets number, leaflet size, $\mathrm{CO}_{2}$-compensation point $(\Gamma)$, leaf-to-air vapor pressure difference $\left(\mathrm{VPD}_{\mathrm{L}}\right)$, intrinsic water-use efficiency $\left(\mathrm{WUE}_{\mathrm{i}}\right)$ in Carapa surinamensis at two water regimes $($ soil at $50 \% \mathrm{FC}$ and soil at $100 \% \mathrm{FC}$ ) under two grown conditions (Experiment 1 at ambient $\mathrm{CO}_{2}$ ) and Experiment 2 (at elevated $\mathrm{CO}_{2}$ ). Means followed by the same letter do not differ significantly $(F$ test at $P=0.05)$. Each value stands for the mean $( \pm \mathrm{SD})$ of five plants $(n=5)$.

\begin{tabular}{|c|c|c|c|c|c|c|}
\hline Parameter/Treatment & $\begin{array}{l}\text { Experiment } 1 \\
100 \% \text { FC }\end{array}$ & $50 \% \mathrm{FC}$ & $\begin{array}{l}\text { Experiment } 2 \\
100 \% \text { FC }\end{array}$ & $50 \% \mathrm{FC}$ & $\begin{array}{l}\text { Mean } \\
\text { Exp. } 1\end{array}$ & $\begin{array}{l}\text { Mean } \\
\text { Exp. } 2\end{array}$ \\
\hline $\begin{array}{l}\Psi_{\mathrm{L}} \text {, at } 06: 00[\mathrm{MPa}] \\
\Psi_{\mathrm{L}} \text { at } 12: 00[\mathrm{MPa}]\end{array}$ & $\begin{array}{l}-0.21 \pm 0.02^{\mathrm{a}} \\
-0.66 \pm 0.03^{\mathrm{a}}\end{array}$ & $\begin{array}{l}-0.35 \pm 0.00^{\mathrm{b}} \\
-0.78 \pm 0.02^{\mathrm{b}}\end{array}$ & $\begin{array}{l}-0.19 \pm 0.01^{\mathrm{a}} \\
-0.47 \pm 0.02^{\mathrm{a}}\end{array}$ & $\begin{array}{l}-0.32 \pm 0.02^{\mathrm{b}} \\
-0.53 \pm 0.03^{\mathrm{b}}\end{array}$ & $\begin{array}{l}-0.28 \pm 0.07 \\
-0.72 \pm 0.06\end{array}$ & $\begin{array}{l}-0.25 \pm 0.07 \\
-0.50 \pm 0.04\end{array}$ \\
\hline Proline $\left[\mathrm{nmol} \mathrm{cm}{ }^{-2}\right]$ & $0.12 \pm 0.06^{\mathrm{a}}$ & $0.13 \pm 0.04^{\mathrm{a}}$ & $0.23 \pm 0.15^{\mathrm{a}}$ & $0.18 \pm 0.05^{\mathrm{a}}$ & $0.12 \pm 0.05$ & $0.21 \pm 0.11$ \\
\hline Leaf number & $21.6 \pm 1.1^{\mathrm{a}}$ & $14.4 \pm 1.8^{\mathrm{b}}$ & $11.8 \pm 1.9^{\mathrm{a}}$ & $11.2 \pm 1.5^{\mathrm{a}}$ & $18.0 \pm 4.1$ & $11.5 \pm 1.6$ \\
\hline Leaflet number & $114.0 \pm 24.4^{\mathrm{a}}$ & $68.0 \pm 8.2^{\mathrm{b}}$ & $77.6 \pm 16.5^{\mathrm{a}}$ & $58.6 \pm 14.8^{\mathrm{a}}$ & $91.0 \pm 29.7$ & $68.1 \pm 17.8$ \\
\hline Leaflet size $\left[\mathrm{cm}^{2}\right]$ & $107.8 \pm 16.0^{\mathrm{a}}$ & $74.0 \pm 15.4^{\mathrm{b}}$ & $170.7 \pm 29.6^{\mathrm{a}}$ & $101.4 \pm 27.1^{\mathrm{b}}$ & $90.9 \pm 23.2$ & $136.0 \pm 45.3$ \\
\hline$\Gamma[\mathrm{ppm}]$ & $54.2 \pm 4.4^{\mathrm{a}}$ & $59.8 \pm 6.2^{\mathrm{a}}$ & $59.5 \pm 1.2^{\mathrm{a}}$ & $57.6 \pm 7.6^{\mathrm{a}}$ & $57.0 \pm 5.8$ & $58.6 \pm 5.2$ \\
\hline $\mathrm{VPD}_{\mathrm{L}}[\mathrm{kPa}]$ & $1.51 \pm 0.05^{\mathrm{a}}$ & $1.60 \pm 0.11^{\mathrm{a}}$ & $1.58 \pm 0.11^{\mathrm{a}}$ & $1.65 \pm 0.13^{\mathrm{a}}$ & $1.55 \pm 0.09$ & $1.61 \pm 0.12$ \\
\hline $\mathrm{WUE}_{\mathrm{i}}\left[\mu \mathrm{mol} \mathrm{mol}{ }^{-1}\right]$ & $77.4 \pm 9.9^{b}$ & $96.1 \pm 10.1^{\mathrm{a}}$ & $164.0 \pm 16.5^{\mathrm{a}}$ & $159.5 \pm 14.8^{\mathrm{a}}$ & $86.8 \pm 13.6$ & $161.8 \pm 15.0$ \\
\hline
\end{tabular}

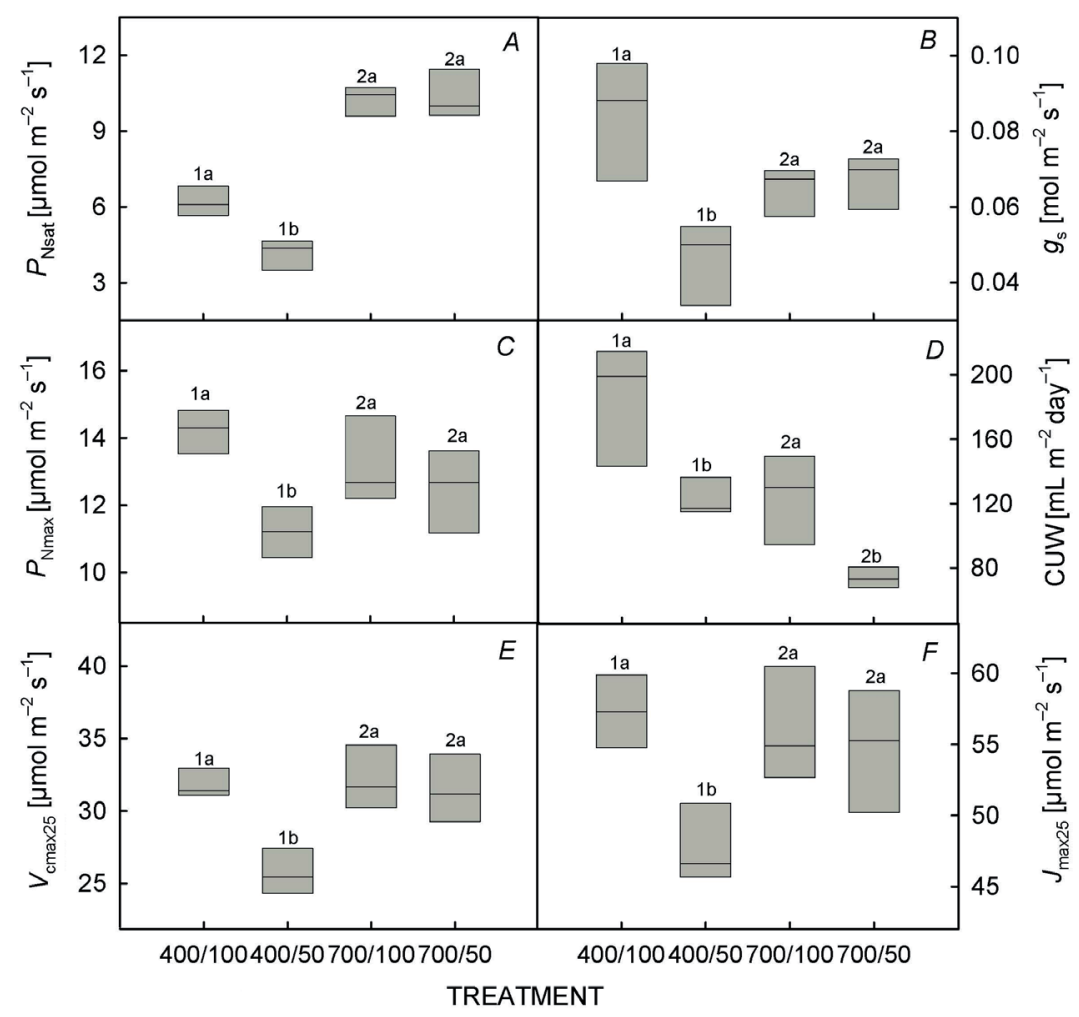

Fig. 1. Physiological parameters of Carapa surinamensis in response to two water regimes (soil at 50\% FC and 100\% FC), under two growth conditions: Experiment 1 (at ambient $\mathrm{CO}_{2}$, about $400 \mathrm{ppm}$ ) and Experiment 2 (at elevated $\mathrm{CO}_{2}, 700$ ppm). Light-saturated net photosynthetic rate $\left(P_{\mathrm{Nsat}}, A\right)$, stomatal conductance $\left(g_{\mathrm{s}}\right)$ at light saturation $(B)$, light and $\mathrm{CO}_{2}$-saturated net photosynthetic rate $\left(P_{\mathrm{Nmax}}, C\right)$, consumptive use of water (CUW, $D)$, maximum carboxylation rate of Rubisco at $25^{\circ} \mathrm{C}\left(V_{\mathrm{cmax} 25}, E\right)$, and maximum electron transport rate at $25^{\circ} \mathrm{C}\left(J_{\max 25}, F\right)$. The numbers (1 or 2) above the box indicate the experiment; boxes (within experiment) with the same letter above are not significantly different ( $F$ test $P \leq 0.05$ ).

dissipated less energy as heat (Fig. 2D), which contributed for $P_{\text {Nat }}$ to increase under elevated $\mathrm{CO}_{2}$.

With respect to plant allometry, we found a large difference in the leaflet size between experiments, which increased by $37 \%$ under water stress and by $58 \%$ in well-watered plants at elevated $\mathrm{CO}_{2}$ (i.e., increase of $50 \%$ over water regimes, Table 1 ). Because there was a reduction in leaf number and leaflet number in Experiment 2 (ambient $v s$. elevated $\mathrm{CO}_{2}$, Table 1), $\mathrm{A}_{\mathrm{L}}$ was similar in both experiments within a water regime (Fig. $3 D$ ). $\mathrm{W}_{\mathrm{T}}$ was greater under elevated $\mathrm{CO}_{2}$ in well-watered plants, but in both experiments, it declined by $42 \%$ under water stress (Fig. 3C). 
Table 2. Summary of the analysis of variance ( $F$ values and $P$ values in parenthesis) on the effect of water regimes on physiological parameters of Carapa surinamensis in Experiment 1 (at ambient $\mathrm{CO}_{2}$ ) and Experiment 2 (at elevated $\mathrm{CO}_{2}$ ). Bold numerals indicate significance $(P \leq 0.05)$. Abbreviations and acronyms as described in the abbreviation's section.

\begin{tabular}{|c|c|c|}
\hline Parameter & Ambient $\mathrm{CO}_{2}$ & Elevated $\mathrm{CO}_{2}$ \\
\hline$\overline{P_{\text {Nsat }}}$ & $26.721(<\mathbf{0 . 0 0 1})$ & $0.143(0.715)$ \\
\hline$g_{\mathrm{s}}$ & $18.530(\mathbf{0 . 0 0 3})$ & $0.202(0.665)$ \\
\hline$P_{\mathrm{Nmax}}$ & $36.518(<\mathbf{0 . 0 0 1})$ & $0.722(0.420)$ \\
\hline CUW & $9.084(\mathbf{0 . 0 1 7})$ & $15.213(\mathbf{0 . 0 0 5})$ \\
\hline$V_{\text {cmax } 25}$ & $37.558(<\mathbf{0 . 0 0 1})$ & $0.190(0.674)$ \\
\hline$J_{\max 25}$ & $21.976(\mathbf{0 . 0 0 2})$ & $0.240(0.637)$ \\
\hline $\mathrm{F}_{\mathrm{v}} / \mathrm{F}_{\mathrm{m}}$ & $3.828(0.086)$ & $0.0611(0.811)$ \\
\hline$\Phi_{\text {PSII }}$ & $17.869(\mathbf{0 . 0 0 3})$ & $30.299(<\mathbf{0 . 0 0 1})$ \\
\hline ETR & $17.869(\mathbf{0 . 0 0 3})$ & $30.299(<\mathbf{0 . 0 0 1})$ \\
\hline NPQ & $1.421(0.267)$ & $0.329(0.582)$ \\
\hline LMA & $6.816(\mathbf{0 . 0 3 1})$ & $0.0164(0.901)$ \\
\hline TNC & $4.780(0.060)$ & $0.000402(0.984)$ \\
\hline $\mathrm{W}_{\mathrm{T}}$ & $6.855(\mathbf{0 . 0 3 1})$ & 8.911 (0.017) \\
\hline $\mathrm{A}_{\mathrm{L}}$ & $10.067(\mathbf{0 . 0 1 3})$ & $21.779(\mathbf{0 . 0 0 2})$ \\
\hline$\Psi_{\mathrm{L}}(6 \mathrm{~h})$ & $162.390(<\mathbf{0 . 0 0 1})$ & $273.067(<\mathbf{0 . 0 0 1})$ \\
\hline$\Psi_{\mathrm{L}}(12 \mathrm{~h})$ & $56.277(<\mathbf{0 . 0 0 1})$ & $12.536(\mathbf{0 . 0 0 8})$ \\
\hline Proline & $0.189(0.675)$ & $0.225(0.648)$ \\
\hline Leaf number & $56.348(<\mathbf{0 . 0 0 1})$ & $0.305(0.596)$ \\
\hline Leaflet number & $15.910(\mathbf{0 . 0 0 4})$ & $3.683(0.091)$ \\
\hline Leaflet size & $11.616(\mathbf{0 . 0 0 9})$ & $14.940(\mathbf{0 . 0 0 5})$ \\
\hline$\Gamma$ & $2.668(0.141)$ & $0.284(0.608)$ \\
\hline $\mathrm{VPD}_{\mathrm{L}}$ & $3.168(0.113)$ & $0.891(0.373)$ \\
\hline WUE $_{\mathrm{i}}$ & $8.702(\mathbf{0 . 0 1 8})$ & $0.202(0.665)$ \\
\hline
\end{tabular}

\section{Discussion}

The RH in the greenhouse was a slightly lower (70-80\% vs. $80-90 \%$ in the growth chamber) and also there could be some differences in light quality between the growth chamber and the greenhouse. Thus, we chose to analyze the data as two experiments instead of using a $2 \times 2$ factorial design. However, some comparison can be made taking into account that temperature and light intensity were similar in both environments, and that the $\mathrm{RH}$ gradient between them was small $(\approx 10 \%)$. The direct effect of a small gradient in temperature seems to have little effect on photosynthetic rates (Lloyd and Farquhar 2008, Yamori et al. 2014). Furthermore, in a previous study we found that in the ranges of $25-30^{\circ} \mathrm{C}$ (temperature) and $72-77 \%$ $(\mathrm{RH}), g_{\mathrm{s}}$ did not decline, actually it tended to increase with temperature (Mendes and Marenco 2017), so it seems unlikely that the small differences in $\mathrm{RH}$ and temperature had a significant effect on carbon uptake.
In well-watered plants, predawn $\Psi_{\mathrm{L}}$ was lower than that one expects from a soil at field capacity (about $-0.01 \mathrm{MPa}$, Slatyer 1967). This shows that there was disequilibrium between pre-dawn $\Psi_{\mathrm{L}}$ and soil water potential, which seems to occurs most of the time (Donovan et al. 2001), and following the increase in transpiration $\Psi_{\mathrm{L}}$ decreased by midday, as expected. Disequilibrium between soil and plant water potential can indicate that the overnight equilibration period is not enough to eliminate internal gradients in water content (Donovan et al. 2001).

In well-watered plants, we found an increase of $64 \%$ in $P_{\text {Nsat }}$ under elevated $\mathrm{CO}_{2}$, but that increase was still higher $(152 \%)$ in plants subjected to water stress. It is worth noting that the exposure to elevated $\mathrm{CO}_{2}$ alleviated the negative effect caused by water stress on $P_{\text {Nsat }}$. The positive effect of the $\mathrm{CO}_{2}$ enrichment on $P_{\text {Nsat }}$ was greater than that reported by Ainsworth and Long (2005), who found that photosynthesis rose about $35 \%$ under elevated $\mathrm{CO}_{2}$ across several $\mathrm{C}_{3}$ species; whereas Nowak et al. (2004) reported that photosynthesis increased by $30-50 \%$ and net primary production about $20 \%$ under elevated $\mathrm{CO}_{2}$.

In well-watered plants, $g_{\mathrm{s}}$ was $24 \%$ lower under elevated $\mathrm{CO}_{2}$. Indeed, the most common response is a decrease of $g_{s}$ under elevated $\mathrm{CO}_{2}$ (Curtis and Wang 1998, Ainsworth and Long 2005, Leakey et al. 2012). Furthermore, we showed that subjecting the plants to elevated $\mathrm{CO}_{2}$ negates the effect of water stress on $g_{\mathrm{s}}$ (i.e., there was no difference in $g_{\mathrm{s}}$ under elevated $\mathrm{CO}_{2}$ ). Consequently, $P_{\text {Nsat }}$ did not decline in water-stressed plants under $\mathrm{CO}_{2}$ enrichment. The sharp drop of $g_{\mathrm{s}}$ at ambient $\mathrm{CO}_{2}$ under water stress was attributed to the lower availability of water in the soil at $50 \% \mathrm{FC}$, rather than to difference in $\mathrm{VPD}_{\mathrm{L}}$, which remained rather constant across experiments (Table 1).

Under ambient $\mathrm{CO}_{2}$ conditions, $P_{\text {Nmax }}$ was lower under water stress ( $P$ value in Table 2$)$, which is consistent with the strong relationship between $g_{\mathrm{s}}$ and $P_{\mathrm{N}}$ (Farquhar and Sharkey 1982, Lloyd and Farquhar 2008, Marenco et al. 2017). However, within a water regime, $P_{\mathrm{Nmax}}$ was similar in both experiments, particularly, in well-watered plants. This suggests absence of photosynthetic acclimation of plants subjected to elevated $\mathrm{CO}_{2}$, which has also been found in other tree species (Ainsworth and Rogers 2007, Leakey et al. 2012). In well-watered plants, $V_{\mathrm{cmax} 25}$ and $J_{\max 25}$ were similar in both experiments, which is in agreement with the result of a meta-analysis carried out by Ainsworth and Long (2005) who found just a slight decline $(6 \%)$ in $V_{\text {cmax }}$ and no effect at all of elevated $\mathrm{CO}_{2}$ on $J_{\max }$. The decline in $V_{\mathrm{cmax} 25}$ and $J_{\max 25}$ found under water stress at ambient $\mathrm{CO}_{2}$ (Fig. 1E) suggests that nonstomatal limitation to photosynthesis increased at ambient $\mathrm{CO}_{2}$. In Olea europaea, for example, at ambient $\mathrm{CO}_{2}$ conditions, up to $60 \%$ of photosynthesis limitation recorded under severe drought can be ascribed to a decline in mesophyll conductance (Perez-Martin et al. 2014). The $J_{\max 25} / V_{\text {cmax25 }}$ ratio was similar in both experiments (about 1.80) and 


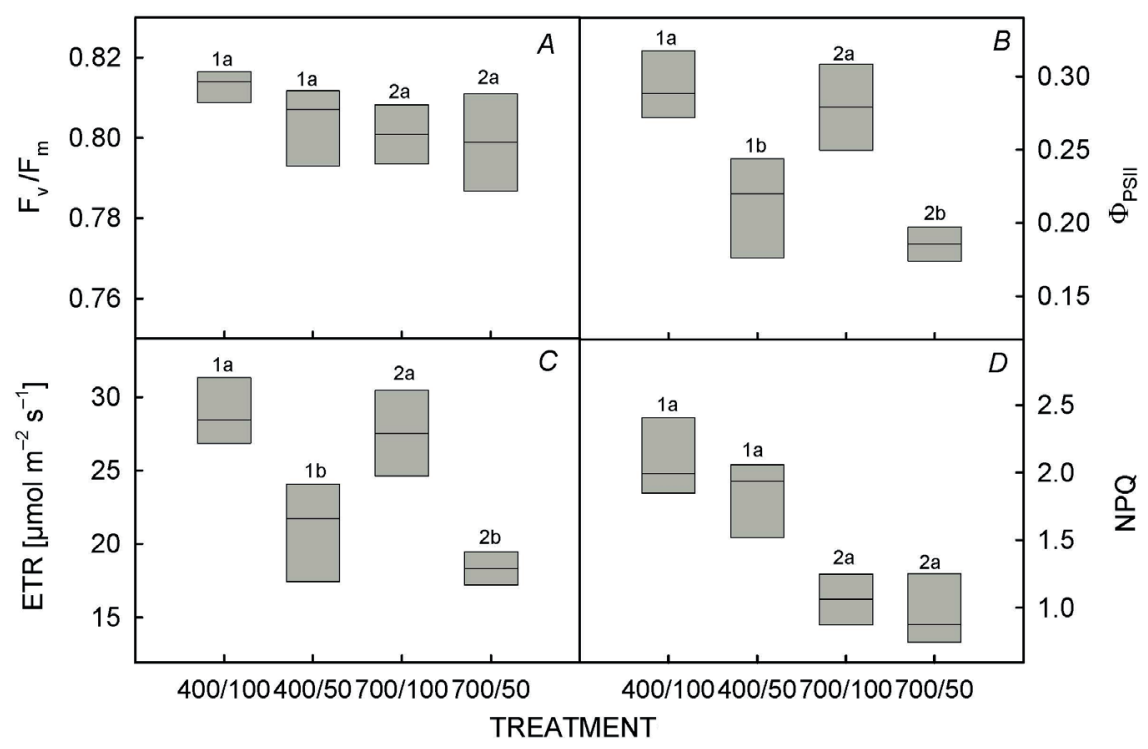

Fig. 2. Fluorescence parameters of Carapa surinamensis in response to two water regimes (soil at 50\% FC and $100 \%$ FC), under two growth conditions: Experiment 1 (at ambient $\mathrm{CO}_{2}$, about $400 \mathrm{ppm}$ ) and Experiment 2 (at elevated $\mathrm{CO}_{2}, 700$ ppm). Maximal quantum yield of PSII photochemistry $\left(\mathrm{F}_{\mathrm{v}} / \mathrm{F}_{\mathrm{m}}, A\right)$; effective quantum yield of PSII photochemistry $\left(\Phi_{\mathrm{PSII}}, B\right)$, electron transport rate $(\mathrm{ETR}, C)$, and nonphotochemical quenching (NPQ, $D)$. The numbers (1 or 2) above the box indicate the experiment; boxes (within experiment) with the same letter above are not significantly different $(F$ test $P \leq 0.05)$.

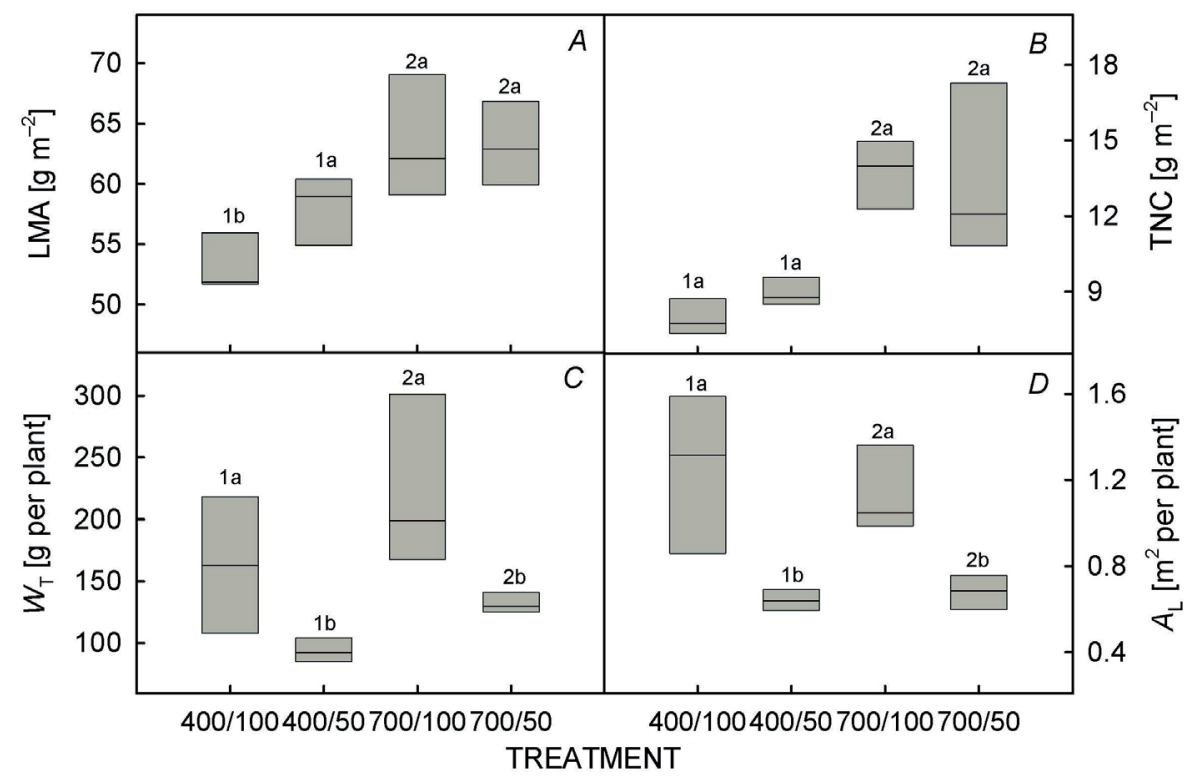

Fig. 3. Leaf mass per area ratio (LMA, $A$ ), total nonstructural carbohydrate (TNC) of leaves $(B)$, total dry matter $\left(\mathrm{W}_{\mathrm{T}}, C\right)$, and total leaf area $\left(\mathrm{A}_{\mathrm{L}}, D\right)$ of Carapa surinamensis in response to two water regimes (soil at $50 \% \mathrm{FC}$ and $100 \% \mathrm{FC}$ ), under two growth conditions: Experiment 1 (at ambient $\mathrm{CO}_{2}$, about $400 \mathrm{ppm}$ ) and Experiment 2 (at elevated $\mathrm{CO}_{2}, 700 \mathrm{ppm}$ ). The numbers (1 or 2 ) above the box indicate the experiment; boxes (within experiment) with the same letter above are not significantly different $(F$ test $P \leq 0.05)$.

close to the value of 1.67 reported by Medlyn et al. (2002). However, it is lower than that of 2.52 ( $V_{\text {cmax }}$ of $42.2 \mu \mathrm{mol}$ $\mathrm{m}^{-2} \mathrm{~s}^{-1}$ ) reported by Manter and Kerrigan (2004) or the value of 2.1 ( $V_{\text {cmax }}$ of $51.0 \mu \mathrm{mol} \mathrm{m} \mathrm{m}^{-2} \mathrm{~s}^{-1}$, for tropical forest species) found by Wullschleger (1993). Our lower $V_{c \max }$ (and $J_{\max }$ ) can be attributed to the fact our plants were grown at mild irradiance. In fact, compared to shade leaves, $P_{\text {Nmax }}$ can double in sun leaves (Marenco et al. 2017). The high correlation between $J_{\max }$ and $V_{\text {cmax }}$ indicates that carbon assimilation is tightly regulated by the amount of resources allocated to the components of the photosynthetic process (Farquhar et al. 1980, Wullschleger 1993).

WUE $E_{i}$ improved at ambient $\mathrm{CO}_{2}$ because the decline of $g_{\mathrm{s}}$ was steeper than that of $P_{\text {Nsat }}(46 \%$ vs. $33 \%)$ under water stress. On the other hand, $\mathrm{WUE}_{\mathrm{i}}$ did not increase in water-stressed plants at elevated $\mathrm{CO}_{2}$ because there was no 
effect of water stress on $g_{\mathrm{s}}$ or $P_{\text {Nsat }}$ under that condition. In comparison with the ambient conditions, the enhancement of $\mathrm{WUE}_{\mathrm{i}}$ in Experiment $2(86 \%)$ can be explained by the increase of $P_{\text {Nsat }}$ at elevated $\mathrm{CO}_{2}$. This improvement is within the range of $76-86 \%$ reported by Drake et al. (1997). The CUW drastically dropped under water stress, particularly under elevated $\mathrm{CO}_{2}$ (Fig. $1 D$ ). This suggests that improvement of $\mathrm{WUE}_{\mathrm{i}}$ and reduction of CUW under elevated $\mathrm{CO}_{2}$ would help the plant to endure prolonged droughts.

Irrespective of $\mathrm{CO}_{2}$ conditions, similar $\mathrm{F}_{\mathrm{v}} / \mathrm{F}_{\mathrm{m}}$ values under drought indicate that exposure to water stress did not impair PSII efficiency, as $\mathrm{F}_{\mathrm{v}} / \mathrm{F}_{\mathrm{m}}$ values close to 0.80 are typically found in nonstressed leaves (Björkman and Demmig 1987). The decline in ETR and $\Phi_{\text {PSII }}$ under water stress was associated with a drop in $P_{\text {Nsat }}$ but that association was not observed when $P_{\mathrm{N}}$ was measured at saturated $\mathrm{CO}_{2}$ conditions $\left(P_{\mathrm{N} \max }\right)$, which indicates that the reduction in $\Phi_{\text {PSII }}$ and ETR is overcome by the increase in $\mathrm{CO}_{2}$ concentration. This occurs because at saturated $\mathrm{CO}_{2}$, photorespiration decreases substantially (Wingler et al. 2000). In rice, severe water stress leads to production of superoxide and malondialdehyde (an indicator of lipid peroxidation) and a drop in $\Phi_{\text {PSII }}$ and $\mathrm{F}_{\mathrm{v}} / \mathrm{F}_{\mathrm{m}}$ (Yang et al. 2014). In this study, it seems unlikely that such severe damage could have occurred as the $\mathrm{F}_{\mathrm{v}} / \mathrm{F}_{\mathrm{m}}$ ratio did not decrease under drought (Table 2). Instead the decline in ETR and $\Phi_{\mathrm{PSII}}$ under water stress can be attributed to an increase in the reduced plastoquinone pool, which can lead to a decrease in photochemical quenching (Maxwell and Johnson 2000). Although it has been found that NPQ can rise under water stress (Tezara et al. 1999, Liu et al. 2017), that effect was not found in this study, which suggests that the water stress applied was severe enough as to induce partial stomatal closure, but at the same time not too strong to increase significantly the loss of energy as heat, perhaps because the plants were grown at a mild light intensity [200 $\mu \mathrm{mol}$ (photon) $\mathrm{m}^{-2} \mathrm{~s}^{-1}$.

In both experiments, $\mathrm{W}_{\mathrm{T}}$ was substantially decreased under water stress (Fig. 3), which can be largely ascribed to the strong reduction in leaf area experienced by waterstressed plants. Under ambient $\mathrm{CO}_{2}$ conditions, $\mathrm{W}_{\mathrm{T}}$ also declined in response to a significant reduction in $P_{\text {Nsat }}$ (Table 2). The strong effect of water stress on leaf area production $\left(A_{L}\right)$ can occur because cell division, leaf expansion, and protein synthesis are impaired by water stress; actually these adjustments occur well before drought could induce stomatal closing (Bradford and Hsiao 1982, Tardieu et al. 2015). Irrespective of the water regimes, $\mathrm{W}_{\mathrm{T}}$ increases by $40 \%$ in plants subjected to elevated $\mathrm{CO}_{2}$ which is in tandem with the increase of $P_{\mathrm{N}}$ with $\mathrm{CO}_{2}$ enrichment. It has been found that across several species above-ground biomass increases by about $20-30 \%$ in plants subjected to elevated $\mathrm{CO}_{2}$ (Curtis and Wang 1998, Ainsworth and Long
2005), whereas starch content increased by $60-80 \%$ under elevated $\mathrm{CO}_{2}$ (Nowak et al. (2004). LMA was greater under elevated $\mathrm{CO}_{2}$, which is consistent with the results reported by others (Eamus et al. 1993, Ainsworth and Long 2005, Aspinwall et al. 2017), and that can be attributed at least in part to the greater content of TNC under elevated $\mathrm{CO}_{2}$ (Fig. 3). One can see in Fig. 3 that within a water regime, $\mathrm{A}_{\mathrm{L}}$ was similar in both experiments, but with a large difference in leaflet size (increase of $50 \%$ at elevated $\mathrm{CO}_{2}$ ) and leaflet number (decrease of 25\% in Experiment 2), which shows that at elevated $\mathrm{CO}_{2}$ a drop in leaf number was offset by an increase in leaf size.

Leaf water potential $\left(\Psi_{\mathrm{L}}\right)$ was lower under drought at ambient $\mathrm{CO}_{2}$, even thought there was no difference in proline content between water regimes, which was unexpected as proline is an osmolyte of common occurrence in plants (Yoshiba et al. 1997). This suggests that (1) the water stress was not too strong to increase proline synthesis or (2) that in Carapa other compatible solutes, such as sugar alcohols or quaternary ammonium compounds (e.g., glycine betaine), can be accumulated instead of proline. For example, in several species (e.g., Pisum sativum and Ricinus communis) sugars are the major osmolytes (Blum 2017). We attributed the higher proline content (per unit area) under elevated $\mathrm{CO}_{2}$ to the greater LMA observed in plants grown in that environment, as LMA is dependent on leaf thickness (Niinemets 1999).

We hypothesized that plants grown at elevated $\mathrm{CO}_{2}$ would respond to $\mathrm{CO}_{2}$ enrichment by improving their photosynthetic performance and their biomass gain, which was confirmed, but in contrast to our hypothesis, WUE $\mathrm{Wid}_{\mathrm{i}}$ not improve at elevated $\mathrm{CO}_{2}$. $\mathrm{WUE}_{\mathrm{i}}$ improved under water stress at ambient $\mathrm{CO}_{2}$ because water stress led to a stronger decline in $g_{\mathrm{s}}$ than in $P_{\mathrm{Nsat}}$, but that effect was not observed at elevated $\mathrm{CO}_{2}$ because in the latter condition there was no effect of water stress on $P_{\text {Nsat }}$ or $g_{\text {s. }}$ Although total leaf area remained rather constant within a water regime, it was observed that the drop in leaflet number under elevated $\mathrm{CO}_{2}$ can be offset by increasing leaflet size, and that subjecting the plants to elevated $\mathrm{CO}_{2}$ entirely negates the effect of water stress of $P_{\mathrm{Nsat}}$ and $g_{\mathrm{s}}$. This study is important because it shows the potential of Carapa to adjust its morphology and physiology either to endure drought or to improve carbon uptake at elevated $\mathrm{CO}_{2}$ conditions. It is shown that water stress leads to a substantial reduction in the CUW by reducing leaf area production and at ambient $\mathrm{CO}_{2}$ also by lowering $g_{\mathrm{s}}$. This adjustment, however, also leads to a strong reduction in total plant biomass. The elevated $\mathrm{CO}_{2}$ conditions negated the effect of water stress on $P_{\mathrm{N}}$, but it only mitigated the effect of water stress on biomass accumulation because of the strong reduction of leaf area in water-stressed plants. These findings widen our understanding to the effect of elevated $\mathrm{CO}_{2}$ on the physiology of Amazonian species. 


\section{References}

Ainsworth E.A., Long S.P.: What have we learned from 15 years of free-air $\mathrm{CO}_{2}$ enrichment (FACE)? A meta-analytic review of the responses of photosynthesis, canopy properties and plant production to rising $\mathrm{CO}_{2}$. - New Phytol. 165: 351-372, 2005.

Ainsworth E.A., Rogers A.: The response of photosynthesis and stomatal conductance to rising $\left[\mathrm{CO}_{2}\right]$ : mechanisms and environmental interactions. - Plant Cell Environ. 30: 258270, 2007.

Aspinwall M.J., Jacob V.K., Blackman C.J. et al.: The temperature response of leaf dark respiration in 15 provenances of Eucalyptus grandis grown in ambient and elevated $\mathrm{CO}_{2} .-$ Funct. Plant Biol. 44: 1075-1086, 2017.

Björkman O., Demmig B.: Photon yield of $\mathrm{O}_{2}$ evolution and chlorophyll fluorescence characteristics at $77 \mathrm{~K}$ among vascular plants of diverse origins. - Planta 170: 489-504, 1987.

Blum A.: Osmotic adjustment is a prime drought stress adaptive engine in support of plant production. - Plant Cell Environ. 40: 4-10, 2017.

Bradford K.J., Hsiao T.C.: Physiological responses to moderate water stress. - In: Lange O.L., Nobel P.S., Osmond C.B., Ziegler H. (ed.): Physiological Plant Ecology II - Water Relation and Carbon Assimilation. Pp. 263-324. SpringerVerlag, Heidelberg 1982.

Camargo M.A., Marenco R.A.: Tree growth over three years in response to monthly rainfall in central Amazonia. Dendrobiology 78: 10-17, 2017.

Cox P.M., Betts R.A., Collins M. et al.: Amazonian forest dieback under climate-carbon cycle projections for the $21^{\text {st }}$ century. Theor. Appl. Climatol. 78: 137-156, 2004.

Curtis P.S., Wang X.: A meta-analysis of elevated $\mathrm{CO}_{2}$ effects on woody plant mass, form, and physiology. - Oecologia 113: 299-313, 1998.

Dias D.P., Marenco R.A.: Tree growth, wood and bark water content of 28 Amazonian tree species in response to variations in rainfall and wood density. - iForest 9: 445-451, 2016.

Donovan L.A., Linton M.J., Richards J.H.: Predawn plant water potential does not necessarily equilibrate with soil water potential under well-watered conditions. - Oecologia 129: 328-335, 2001.

Drake B.G., Gonzàlez-Meler M.A., Long S.P.: More efficient plants: a consequence of rising atmospheric $\mathrm{CO}_{2}$ ? - Annu. Rev. Plant. Phys. 48: 609-639, 1997.

Duffy P.B., Brando P., Asner G.P., Field C.B.: Projections of future meteorological drought and wet periods in the Amazon. - P. Natl. Acad. Sci. USA 112: 13172-13177, 2015.

Eamus D., Berryman C.A., Duff G.A.: Assimilation, stomatal conductance, specific leaf area and chlorophyll responses to elevated $\mathrm{CO}_{2}$ of Maranthes corymbosa, a tropical monsoon rain forest species. - Aust. J. Plant Physiol. 20: 741-755, 1993.

Farquhar G.D., Sharkey T.D.: Stomatal conductance and photosynthesis. - Annu. Rev. Plant Physio. 33: 317-345, 1982.

Farquhar G.D., von Caemmerer S., Berry J.A.: A biochemical model of photosynthetic $\mathrm{CO}_{2}$ assimilation in leaves of $\mathrm{C}_{3}$ species. - Planta 149: 78-90, 1980.

Gibon Y., Sulpice R., Larher F.: Proline accumulation in canola leaf discs subjected to osmotic stress is related to the loss of chlorophylls and to the decrease of mitochondrial activity. Physiol. Plantarum 110: 469-476, 2000.

Gunderson C.A., Wullschleger S.D.: Photosynthetic acclimation in trees to rising atmospheric $\mathrm{CO}_{2}$ : a broader perspective. Photosynth. Res. 39: 369-388, 1994.

Kirschbaum M.U.F.: The sensitivity of $\mathrm{C}_{3}$ photosynthesis to increasing $\mathrm{CO}_{2}$ concentration: a theoretical analysis of its dependence on temperature and background $\mathrm{CO}_{2}$ concentration. - Plant Cell Environ. 17: 747-754, 1994.

Leakey A.D., Ainsworth E.A., Bernacchi C.J. et al.: Photosynthesis in a $\mathrm{CO}_{2}-$ rich atmosphere. - In: Eaton-Rye J.J., Tripathy B.C., Sharkey T.D. (ed.): Photosynthesis: Plastid Biology, Energy Conversion and Carbon Assimilation. Pp. 733-768. Springer, Dordrecht 2012.

Liu C., Wang Y., Jin Y. et al.: Photoprotection regulated by phosphorus application can improve photosynthetic performance and alleviate oxidative damage in dwarf bamboo subjected to water stress. - Plant Physiol. Bioch. 118: 88-97, 2017.

Lloyd J., Farquhar G.D.: Effects of rising temperatures and $\left[\mathrm{CO}_{2}\right]$ on the physiology of tropical forest trees. - Philos. T. Roy. Soc. B 363: 1811-1817, 2008.

Manter D.K., Kerrigan J.: $A / C_{\mathrm{i}}$ curve analysis across a range of woody plant species: influence of regression analysis parameters and mesophyll conductance. - J. Exp. Bot. 55: 2581-2588, 2004.

Marenco R.A., Camargo M.A.B., Antezana-Vera S.A., Oliveira M.F.: Leaf trait plasticity in six forest tree species of central Amazonia. - Photosynthetica 55: 679-688, 2017.

Maxwell K., Johnson G.N.: Chlorophyll fluorescence - a practical guide. - J. Exp. Bot. 51: 659-668, 2000

Medlyn B.E., Dreyer E., Ellsworth D. et al.: Temperature response of parameters of a biochemically based model of photosynthesis. II. A review of experimental data. - Plant Cell Environ. 25: 1167-1179, 2002.

Mendes K.R., Marenco R.A.: Stomatal opening in response to the simultaneous increase in vapor pressure deficit and temperature over a 24-h period under constant light in a tropical rainforest of the central Amazon. - Theor. Exp. Plant Physiol. 29: 187-194, 2017.

Moore B.D., Cheng S.H., Sims D., Seemann J.R.: The biochemical and molecular basis for photosynthetic acclimation to elevated atmospheric $\mathrm{CO}_{2}$. - Plant Cell Environ. 22: 567-582, 1999.

Nascimento H.C.S., Marenco R.A.: Mesophyll conductance variations in response to diurnal environmental factors in Myrcia paivae and Minquartia guianensis in Central Amazonia. - Photosynthetica 51: 457-464. 2013.

Niinemets Ü.: Components of leaf dry mass per area-thickness and density-alter leaf photosynthetic capacity in reverse directions in woody plants. - New Phytol. 144: 35-47, 1999.

Nowak R.S., Ellsworth D.S., Smith S.D.: Functional responses of plants to elevated atmospheric $\mathrm{CO}_{2}-$ do photosynthetic and productivity data from FACE experiments support early predictions? - New Phytol. 162: 253-280, 2004.

Papageorgiou G.C., Govindjee: The non-photochemical quenching of the electronically excited state of chlorophyll a in plants: definitions, timelines, viewpoints, open questions. - In: Demmig-Adams B., Garab G., Adams W., Govindjee (ed.): Non-Photochemical Quenching and Energy Dissipation in Plants, Algae and Cyanobacteria. Pp. 1-44. Springer, Dordrecht 2014.

Perez-Martin A., Michelazzo C., Torres-Ruiz J.M. et al.: Regulation of photosynthesis and stomatal and mesophyll conductance under water stress and recovery in olive trees: correlation with gene expression of carbonic anhydrase and aquaporins. - J. Exp. Bot. 65: 3143-3156, 2014.

Rogers A., Fischer B.U., Bryant J. et al.: Acclimation of photosynthesis to elevated $\mathrm{CO}_{2}$ under low-nitrogen nutrition is affected by the capacity for assimilate utilization. Perennial ryegrass under free-air $\mathrm{CO}_{2}$ enrichment. - Plant Physiol. 118: 683-689, 1998.

Saatchi S.S., Houghton R.A., Alvala R.C.D.S. et al.: Distribution 
of aboveground live biomass in the Amazon Basin. - Glob. Change Biol. 13: 816-837, 2007.

Salati E.: The forest and the hydrological cycle. - In: Dickinson R.E. (ed.): The Geophysiology of Amazonia: Vegetation and Climate Interactions. Pp. 273-296. John Wiley, New York 1987.

Slatyer R.O.: Plant-Water Relationships. Pp. 65-93. Academic Press, New York 1967.

Tardieu F., Simonneau T., Parent B.: Modelling the coordination of the controls of stomatal aperture, transpiration, leaf growth, and abscisic acid: update and extension of the Tardieu-Davies model. - J. Exp. Bot. 66: 2227-2237, 2015.

Tezara W., Mitchell V.J., Driscoll S.D., Lawlor D.W.: Water stress inhibits plant photosynthesis by decreasing coupling factor and ATP. - Nature 401: 914-917, 1999.

von Caemmerer S.: Biochemical Models of Leaf Photosynthesis. Pp. 1-71. Csiro Publishing, Collingwood 2000.

Way D.A., Oren R.A.M., Kroner Y.: The space-time continuum: the effects of elevated $\mathrm{CO}_{2}$ and temperature on trees and the importance of scaling. - Plant Cell Environ. 38: 991-1007, 2015.

Wullschleger S.D.: Biochemical limitations to carbon assimilation in $\mathrm{C}_{3}$ plants - a retrosprective analysis of the $A$ / $C_{\mathrm{i}}$ curves from 109 species. - J. Exp. Bot. 44: 907-920, 1993.

Yamori W., Hikosaka K., Way D.A.: Temperature response of photosynthesis in $\mathrm{C}_{3}, \mathrm{C}_{4}$, and CAM plants: temperature acclimation and temperature adaptation. - Photosynth. Res. 119: 101-117, 2014.

Yang P.M., Huang Q.C., Qin G.Y. et al.: Different drought-stress responses in photosynthesis and reactive oxygen metabolism between autotetraploid and diploid rice. - Photosynthetica 52: 193-202, 2014.

Yoshiba Y., Kiyosue T., Nakashima K. et al.: Regulation of levels of proline as an osmolyte in plants under water stress. - Plant Cell Physiol. 38: 1095-1102, 1997.

Wingler A., Lea P.J., Quick W.P., Leegood R.C.: Photorespiration: metabolic pathways and their role in stress protection. Philos. T. Roy. Soc. B 355: 1517-1529, 2000.

(C) The authors. This is an open access article distributed under the terms of the Creative Commons BY-NC-ND Licence. 